\title{
CARDIOVASCULAR DISEASES AND AIR POLLUTION IN NOVI SAD, SERBIA
}

\author{
MARIJA JEVTIĆ ${ }^{1,2}$, NATAŠA DRAGIĆ ${ }^{1,2}$, SANJA BIJELOVIĆ ${ }^{1,2}$, and MILKA POPOVIĆ ${ }^{1,2}$ \\ ${ }^{1}$ University of Novi Sad Faculty of Medicine, Novi Sad, Serbia \\ ${ }^{2}$ Institute of Public Health of Vojvodina, Novi Sad, Serbia \\ Center for Hygiene and Human Ecology
}

\begin{abstract}
Objectives: A large body of evidence has documented that air pollutants have adverse effect on human health as well as on the environment. The aim of this study was to determine whether there was an association between outdoor concentrations of sulfur dioxide $\left(\mathrm{SO}_{2}\right)$ and nitrogen dioxide $\left(\mathrm{NO}_{2}\right)$ and a daily number of hospital admissions due to cardiovascular diseases (CVD) in Novi Sad, Serbia among patients aged above 18. Material and Methods: The investigation was carried out during over a 3-year period (from January 1, 2007 to December 31, 2009) in the area of Novi Sad. The number $(\mathrm{N}=10469)$ of daily CVD (ICD-10: I00-I99) hospital admissions was collected according to patients' addresses. Daily mean levels of $\mathrm{NO}_{2}$ and $\mathrm{SO}_{2}$, measured in the ambient air of Novi Sad via a network of fixed samplers, have been used to put forward outdoor air pollution. Associations between air pollutants and hospital admissions were firstly analyzed by the use of the linear regression in a single polluted model, and then trough a single and multi-polluted adjusted generalized linear Poisson model. Results: The single polluted model (without confounding factors) indicated that there was a linear increase in the number of hospital admissions due to CVD in relation to the linear increase in concentrations of $\mathrm{SO}_{2}(\mathrm{p}=0.015 ; 95 \%$ confidence interval $\left.(95 \% \mathrm{CI}): 0.144-1.329, \mathrm{R}^{2}=0.005\right)$ and $\mathrm{NO}_{2}\left(\mathrm{p}=0.007 ; 95 \% \mathrm{CI}: 0.214-1.361, \mathrm{R}^{2}=0.007\right)$. However, the single and multi-polluted adjusted models revealed that only $\mathrm{NO}_{2}$ was associated with the CVD $(\mathrm{p}=0.016$, relative risk $(\mathrm{RR})=1.049,95 \%$ CI: $1.009-1.091$ and $\mathrm{p}=0.022, \mathrm{RR}=1.047,95 \% \mathrm{CI}: 1.007-1.089$, respectively). Conclusions: This study shows a significant positive association between hospital admissions due to CVD and outdoor $\mathrm{NO}_{2}$ concentrations in the area of Novi Sad, Serbia.
\end{abstract}

Key words:

Ambient air pollution, Cardiovascular diseases, Patient admission, Effects of pollutants, Exposure-outcome relation

\section{INTRODUCTION}

In a huge number of references, adverse effects of air pollutants on respiratory diseases are well described [1-4]. However, in a recent period a number of papers suggest that air pollution may be associated with cardiovascular diseases [5-7]. According to Martins et al.'s opinion [8], the number of adverse health outcomes attributable to air pollutants is much larger for cardiovascular than for respiratory diseases and the elderly people are the ones who present the highest susceptibility.

Most of the observations across North America $[9,10]$, Australia [11], China [12], Europe [13-15], Mediterranean area [16] and in some cities in south Serbia [17] have already examined the relationship between cardiovascular admissions and urban air pollution, but in the area of Novi Sad, Serbia, this relationship has not been assessed yet.

Financial support of the Ministry of Education Science and Technological Development of Serbia, project Biosensing Technologies and Global System for Continuous Research and Integrated Management, No. 43002. Coordinator: Miroslav Veskovic, PhD.

Received: September 26, 2013. Accepted: January 21, 2014.

Corresponding author: M. Jevtić, Institut of Public health of Vojvodina, Center for Hygiene and Human Ecology, Futoška 121, 21000 Novi Sad, Serbia (e-mail: marija.jevtic@uns.ac.rs). 
A significant number of time-series studies [18-23] indicate predominant effects of particulates and carbon monoxide (CO) on CVD admissions. However, Burnet et al. [24] who examined association between air pollution and admissions due to CVD in Canada in a series of papers, report that this association could be explained by the effects of gases. Investigations conducted by Poloniecki et al. [13], Pönka et al. [25] or Morgan et al. [11] suggest independent effects of the nitrogen dioxide $\left(\mathrm{NO}_{2}\right)$ and sulphur dioxide $\left(\mathrm{SO}_{2}\right)$.

The aim of this study was to determine whether there was an association between outdoor concentrations of sulfur dioxide $\left(\mathrm{SO}_{2}\right)$ and nitrogen dioxide $\left(\mathrm{NO}_{2}\right)$ and the daily number of hospital admissions due to all cardiovascular diseases (CVD) in Novi Sad, Serbia, in the case of patients aged above 18 .

\section{MATERIAL AND METHODS}

The investigation was carried out during the period from January 1, 2007 to December 31, 2009 in the area of Novi Sad. Novi Sad, the second largest city in Serbia, is located in the northern part of the country (Province of Vojvodina) and according to the data from 2009, it has a population of 285756 inhabitants in a built-up area of approximately $60 \mathrm{~km}^{2}$ [26].

The daily number of hospital admissions ( $\mathrm{N}=1093$ days) due to all CVD (ICD-10: I00-I99) [27] was obtained from the Centre for Informatics and Biostatistics in health care of the IPHV according to addresses of the patients (if the patients were not residents of Novi Sad, they were not included in the analysis). In addition to the data on the daily number of hospital admissions during the observed period, data on the age of the hospitalized individuals were available. However, only the daily number of hospital admissions of individuals older than 18 years of age (with no upper age limit) was taken into consideration.
Daily mean levels of nitrogen dioxide $\left(\mathrm{NO}_{2}\right)$ and sulfur dioxide $\left(\mathrm{SO}_{2}\right)$, measured in the ambient air of Novi Sad via a network of fixed samplers, have been used to put forward outdoor air pollution. There were 10 fixed monitoring sites spread all over the city, although not all of them measured all air pollutants. $\mathrm{NO}_{2}$ from 2 stations and $\mathrm{SO}_{2}$ from 10 stations were measured in the period from 0:00 a.m. to 12:00 p.m. and determined as the 24 h-average values using the spectrophotometric and volumetric methods, respectively, in 1092 air samples [28]. Because of the laboratory limit value for the performed methodology (for $\mathrm{SO}_{2}<2 \mu \mathrm{g} / \mathrm{m}^{3}$ and for $\mathrm{NO}_{2}<4 \mu \mathrm{g} / \mathrm{m}^{3}$ ), concentrations of each measured gaseous air pollutant were categorized into 2 categories, as follows:

- $\mathrm{SO}_{2}$ I category - concentrations $<2 \mu \mathrm{g} / \mathrm{m}^{3}$,

- $\mathrm{SO}_{2}$ II category - concentrations $\geq 2 \mu \mathrm{g} / \mathrm{m}^{3}$,

- $\mathrm{NO}_{2}$ I category - concentrations $<4 \mu \mathrm{g} / \mathrm{m}^{3}$,

- $\mathrm{NO}_{2}$ II category - concentrations $\geq 4 \mu \mathrm{g} / \mathrm{m}^{3}$.

Such a division of data concerning air pollutants was necessary for data processing. Specifically speaking, in the examined 3-year period the values were below the limit of laboratory detection for $\mathrm{SO}_{2}$ for over $63.4 \%$ of days and $\mathrm{NO}_{2}$ over $55.1 \%$ was not noted as a numerical value, but exclusively as a nominal value $<2 \mu \mathrm{g} / \mathrm{m}^{3}$, i.e. $<4 \mu \mathrm{g} / \mathrm{m}^{3}$. Data on the daily mean air temperature and daily mean relative humidity were provided by the Republic Hydrometeorological Institute of Serbia [29].

\section{Statistics}

Beside descriptive statistics, the nature and strength of the association between $\mathrm{NO}_{2}$ and $\mathrm{SO}_{2}$ concentration and hospital admissions were analyzed using various analytical techniques. Spearman's rank correlation was performed for the inter-correlation check between the observed variables; the $\mathrm{Chi}^{2}$ test and independent T-test were used for the seasonal change trend of $\mathrm{NO}_{2}, \mathrm{SO}_{2}$ and $\mathrm{CVD}$ admissions, respectively. After log transformation of the daily CVD admissions, the air pollutant exposure-outcome 
relationship has been first examined using the univariate linear regression model for the whole observed period.

However, due to the potential impact of confounding factors (long term, season, days of the week, weather components) on the examined relationship, CVD admissions were then regressed throughout multiple linear regression models. For assessing the core model that explained the relationship between air pollutants and CVD, long term (day of the study), season (each year was divided into the summer season from March 21 to September 22 and the winter season from September 23 to March 20), days of the week, temperature and relative humidity were used. The contribution of each confounding factor to the model fitting was assessed by stepwise multiple regressions and then regarded in relation to the coefficient of F test according to the level of significance. The final model (without air pollutants) included: long term period as a linear term, days of the week as a dummy variable (working day coding with 0 and weekend day coding with 1) temperature as linear and quadratic terms, while relative humidity as a linear term and season as a dummy variable were not significant. Different shapes of functions were constructed in order to find the best fit of exposure-response relationship model. In order to check the adequacy of each model, spectral analysis, peridiograms, plots of residuals and QQ plots were used. To confirm that autocorrelation among regression residuals was not diagnosed, the Durbin-Watson test was used (a range between 1.5-2.5 was used to confirm the absence of autocorrelation) [30].

After establishing this core model, the significant association - detected using the single polluted model analysis, was evaluated by the generalized linear Poisson regression model $[31,32]$ in relation to the daily number of hospital admissions due to CVD. Daily concentrations of each air pollutant were included in the model as dummy variables (I category of $\mathrm{SO}_{2}$ and $\mathrm{NO}_{2}$ was coded as 0 , while II category of $\mathrm{SO}_{2}$ and $\mathrm{NO}_{2}$ was coded as 1). All the analyses were based on exposures on the day of admission. Relative risk (RR) with 95\% confidence intervals $(95 \% \mathrm{CI})$ for each air pollutant was obtained in the single polluted and multi-polluted models. The results are also presented as a percentage increase associated with a unit increase in the pollutant level by the formula:

$$
100 \times(1-\exp (\beta \text { coefficient } \times 1)-1)
$$

where:

exp - exponential functions,

$\beta$ - the estimated regression coefficient for pollutant.

$1 \%$ relative increase corresponded to the relative risk of 1.01. A significance level of $5 \%$ ( 2 sided) was used. SPSS for Windows (version 17.0) was used for all data analyses.

\section{RESULTS}

Over the 3-year period (1093 days), in the study area there were 10469 CVD admissions among persons aged between minimum 18 and maximum 102 years. The average age of the hospitalized persons equaled $64.24 \pm 13.19$ years, while the mean daily number of CVD hospital admissions was $9(\overline{\mathrm{X}}=9.57 \pm 4.81)$, and it ranged from 0 to maximum 27 admissions during one day (Table 1). Troughout the whole study period, the average daily concentrations of $\mathrm{SO}_{2}$ were $16.33 \mu \mathrm{g} / \mathrm{m}^{3}$ with maximum $31 \mu \mathrm{g} / \mathrm{m}^{3}$ (for the $36.6 \%$ of observed days), while for the $\mathrm{NO}_{2}$ they were $19.93 \mu \mathrm{g} / \mathrm{m}^{3}$ (for the $44.9 \%$ of observed days) with the maximum level of $137 \mu \mathrm{g} / \mathrm{m}^{3}$. The average daily temperature and relative humidity were $12.51^{\circ} \mathrm{C}$ and $71.05 \%$, respectively (Table 1). The values of Spearman's correlations coefficients (Table 2) suggest the lack of relationship between concentration of $\mathrm{SO}_{2}, \mathrm{NO}_{2}$, temperature and relative humidity. Only temperature was positively associated with relative humidity $(r=0.575, \mathrm{p}<0.000)$.

Based on the season specific statistics, daily hospital admissions due to all CVD did not show seasonal change $(\mathrm{t}=0.724 ; \mathrm{p}=0.470)$ throughout the whole observed period of time (Table 3 ), while seasonal variations 
Table 1. Summary statistics of daily hospital admissions due to cardiovascular diseases (CVD), air pollution and weather variables trough the observed period i.e. 2007-2009

\begin{tabular}{lcrrr}
\hline \multicolumn{1}{c}{$\begin{array}{c}\text { Variable } \\
\text { (observed days) }\end{array}$} & $\overline{\mathrm{X}}$ & $\mathrm{SD}$ & Min. & Max \\
\hline CVD hospital admissions $(\mathrm{N}=1093)$ & 9.57 & 4.81 & 0.00 & 27.00 \\
Age of hospitalized patients & 64.24 & 13.19 & 18.00 & 102.00 \\
Temperature $(\mathrm{N}=1093)$ & 12.51 & 8.36 & -12.00 & 29.70 \\
Relative humidity $(\mathrm{N}=1093)$ & 71.05 & 14.39 & 21.00 & 99.00 \\
$\mathrm{SO}_{2}{ }^{*}$ II category $(\mathrm{N}=400)$ & 16.33 & 4.33 & 2.00 & 31.00 \\
$\mathrm{NO}_{2}{ }^{*}$ II category $(\mathrm{N}=491)$ & 19.93 & 18.36 & 4.00 & 137.00 \\
\hline
\end{tabular}

* For the rest of the observed days, concentration of $\mathrm{SO}_{2}$ and $\mathrm{NO}_{2}$ were analyzed as $\mathrm{SO}_{2} \mathrm{I}$ category - concentrations of $\mathrm{SO}_{2}<2 \mu \mathrm{g} / \mathrm{m}^{3}$ and $\mathrm{NO}_{2} \mathrm{I}$ category - concentrations of $\mathrm{NO}_{2}<4 \mu \mathrm{g} / \mathrm{m}^{3}$, respectively.

$\mathrm{SO}_{2}$ - sulfur dioxide; $\mathrm{NO}_{2}$ - nitrogen dioxide.

$\overline{\mathrm{X}}$ - mean; SD - standard deviation.

Min. - minimum; Max - maximum.

Table 2. Spearman's correlations coefficients among the key variables, Novi Sad, 2007-2009

\begin{tabular}{|c|c|c|c|c|c|c|c|c|}
\hline \multirow{2}{*}{ Variable } & \multicolumn{2}{|c|}{$\mathrm{SO}_{2}$} & \multicolumn{2}{|c|}{$\mathrm{NO}_{2}$} & \multicolumn{2}{|c|}{ Temperature } & \multicolumn{2}{|c|}{ Air humidity } \\
\hline & $\mathrm{r}$ & $\mathrm{p}$ & $\mathrm{r}$ & $\mathrm{p}$ & $\mathrm{r}$ & $\mathrm{p}$ & $\mathrm{r}$ & $\mathrm{p}$ \\
\hline $\mathrm{SO}_{2}$ & & & -0.063 & 0.017 & -0.082 & 0.028 & -0.067 & 0.026 \\
\hline $\mathrm{NO}_{2}$ & & & & & -0.067 & 0.026 & -0.048 & 0.170 \\
\hline Temperature & & & & & & & -0.575 & 0.000 \\
\hline Air humidity & & & & & & & & \\
\hline
\end{tabular}

$\mathrm{r}$ - Spearman's coefficient.

Other abbreviations as in Table 1.

Table 3. Season - specific statistics for air pollutants and the daily number of hospital admissions due to cardiovascular diseases (CVD) over the years 2007-2009

\begin{tabular}{lcccc}
\hline \multicolumn{1}{c}{ Variables of interest } & Winter season & Summer season & $\chi^{2}$ & $\mathrm{p}$ \\
\hline $\mathrm{SO}_{2}$ concentration - days $(\%)$ & & & & \\
$\mathrm{SO}_{2}$ I category & 47.20 & 52.80 & 4.045 & 0.044 \\
$\mathrm{SO}_{2}$ II category & 53.50 & 36.60 & & \\
$\mathrm{NO}_{2}$ concentration - days $(\%)$ & & & & \\
$\mathrm{NO}_{2}$ I category & 44.00 & 55.40 & 10.200 & 0.006 \\
$\mathrm{NO}_{2}$ II category & 53.50 & 46.50 & & $\mathrm{p}$ \\
& & & $\mathrm{t}$ & 0.470 \\
$\mathrm{CVD}$ admissions $(\overline{\mathrm{X}} \pm \mathrm{SD})$ & $9.77 \pm 5.21$ & $9.34 \pm 4.39$ & 0.724 & \\
\hline
\end{tabular}

$\chi^{2}-$ Chi square.

Other abbreviations as in Table 1. 
of air pollutants were characterized by a significantly higher number of days with higher concentrations of $\mathrm{SO}_{2}$ $\left(\chi^{2}=4.045 ; p=0.044\right)$ and $\mathrm{NO}_{2}\left(\chi^{2}=10.200 ; p=0.006\right)$ in the winter and smaller in the summer season (Table 3 ). Data on all cardiovascular diseases and daily $\mathrm{SO}_{2}$ and $\mathrm{NO}_{2}$ concentrations obtained in the single linear regression show that $\mathrm{NO}_{2}$ and $\mathrm{SO}_{2}$ were significant predictors of hospital admissions, with a $95 \% \mathrm{CI}$ for the $\mathrm{NO}_{2}$ of $0.214-1.361(\mathrm{p}=0.007)$ and for the $\mathrm{SO}_{2}$ of $0.144-1.329$ $(\mathrm{p}=0.015)$. Coefficient of determination $\left(\mathrm{R}^{2}\right)$ for $\mathrm{SO}_{2}$ in the single polluted model was 0.005 , while for $\mathrm{NO}_{2}$ it was 0.007 (Table 4).

Adjusted Poisson regression model (Table 5) indicated that only concentrations of $\mathrm{NO}_{2}$ were significantly associated with the daily number of hospital admissions due to CVD. In the single polluted model, just like in the multiple polluted model, RR for $\mathrm{NO}_{2}$ was 1.049 (95\% CI: 1.009$1.091)$ and 1.047 (95\% CI: 1.007-1.089), respectively.

\section{DISSCUSION}

This is the first study examining effects of gaseous air pollution on all CVD hospital admissions in Novi Sad, Serbia. As we expected, the levels of gaseous pollution in the area of Novi Sad were moderate. The average daily values of $\mathrm{SO}_{2}$ and $\mathrm{NO}_{2}$ troughout the whole period of investigation were bellow the National Standard [33] and WHO recommendations [34,35].

A seasonal variation of $\mathrm{NO}_{2}$ and $\mathrm{SO}_{2}$ concentrations revealed a noticeable winter peak. Similar results were reported by other authors [36,37]. The higher number of days with concentration of $\mathrm{SO}_{2}>2 \mu \mathrm{g} / \mathrm{m}^{3}$ during the

Table 4. Association between the monitored components of air pollution and the daily hospital admissions due to cardiovascular diseases throughout the 3-year period - results of the single linear regression model without confounding

\begin{tabular}{lcccccc}
\hline \multirow{2}{*}{ Pollutants } & $\beta$ coefficients & \multirow{2}{*}{$\mathrm{R}^{2}$} & $\mathrm{~F}$ & $\mathrm{p}$ & \multicolumn{2}{c}{ 95\% CI for $\beta$} \\
\cline { 6 - 7 } & & & & & & \\
$\mathrm{SO}_{2}$ & 0.736 & 0.005 & 5.945 & 0.015 & 0.144 & 1.329 \\
$\mathrm{NO}_{2}$ & 0.787 & 0.007 & 7.259 & 0.007 & 0.214 & 1.361 \\
\hline
\end{tabular}

$\beta$ - regression coefficients.

$\mathrm{F}$ - Fisher value.

$\mathrm{CI}$ - confidence interval.

Other abbreviations as in Table 1.

Table 5. Adjusted Poisson regression model ${ }^{\mathrm{a}}$ - association between the gaseous air pollution and cardiovascular diseases admissions in 2007-2009 period, Novi Sad

\begin{tabular}{lccccc}
\hline \multirow{2}{*}{ Pollutants } & \multirow{2}{*}{$\beta$ coefficients } & RR & p value & lower bound & upper bound \\
\hline $\mathrm{SO}_{2}$ II category* & -0.039 & 0.962 & 0.262 & 0.900 & 1.029 \\
$\mathrm{NO}_{2}$ II category* & 0.048 & 1.049 & 0.016 & 1.009 & 1.091 \\
$\mathrm{SO}_{2}$ II category** & -0.029 & 0.972 & 0.409 & 0.908 & 1.040 \\
$\mathrm{NO}_{2}$ II category** & 0.046 & 1.047 & 0.022 & 1.007 & 1.089 \\
\hline
\end{tabular}

${ }^{a}$ Model adjusted for long term, weekend and temperature.

Category of $\mathrm{SO}_{2}$ and $\mathrm{NO}_{2}$ is regarded as the reference category in: * single polluted model and ** multi-polluted model.

$\mathrm{RR}$ - relative risk; $\beta$ - regression coefficients. 
winter season could be related to the increased combustion of fuel used for domestic heating [38]. Zhao et al. [39] suggest that seasonal variability of $\mathrm{NO}_{2}$ may result mainly from seasonal changes in chemical loss of NOx, which is very high in the summer and very low during the winter. Also, the increased atmospheric stability in the winter period may lead to a built up concentration of ambient air pollutants [40,41]. Attempting to investigate the role of $\mathrm{SO}_{2}, \mathrm{NO}_{2}$, particulate matter, temperature, relative humidity and wind speed in respiratory admissions (COPD, asthma and emphysema) Agarwal et al. [42] show that winter months have greater exposure risk as pollutants often get trapped in the lower layers of atmosphere resulting in high concentrations. However, there is no seasonal pattern for the date of daily hospital admissions for all cardiovascular diseases. Although we do expect similar change like with the gaseous air pollution, this could be explained by the influence of some other confounding factors which we have not taken into consideration. Research conducted by Kovats and colleagues confirm phenomena similar to ours in London [43]. However, in Spain, Valencia, cardiovascular admission series presented a seasonal trend with higher numbers in the coldest months [15].

In accordance with the aim of this study, we have found statistically significant, positive associations between the daily hospital admissions due to all CVD for the patients aged above 18 and the measured levels of gaseous pollutants.

The coefficient of determination indicated that only $0.7 \%$ and $0.5 \%$ of the variation in admissions could be explained by $\mathrm{NO}_{2}$ and $\mathrm{SO}_{2}$ (respectively). According to some other results [44], it is a very small predictable percent.

These results have to be considered with caution because they did not include some important factors like long term fluctuations, seasonal variations or day of the week, which may contribute to some associations between air pollution and CVD diseases [45]. Also, the studies suggest that differences in temperature and humidity might influence the composition of air pollution mix and therefore, might play a part in its effect on human health [46,47].

In the Poisson regression model with air pollutants and all significant confounding variables (long term, weekend and temperature) taken into account, the effects attributable to $\mathrm{NO}_{2}$ and $\mathrm{SO}_{2}$ change slightly - only $\mathrm{NO}_{2}$ shows independently significant association with admissions due to CVD, while $\mathrm{SO}_{2}$ remains insignificant. According to partial regression coefficients of the $\mathrm{NO}_{2}$ and corresponding $\mathrm{RR}$ of hospital admissions in the single and multi-polluted models, each increase in the concentration of $\mathrm{NO}_{2}$ by $1 \mu \mathrm{g} / \mathrm{m}^{3}$ in the days when $\mathrm{NO}_{2}$ concentration was $>4 \mu \mathrm{g} / \mathrm{m}^{3}$ compared to the days when $\mathrm{NO}_{2}$ concentration was $<4 \mu \mathrm{g} / \mathrm{m}^{3}$ contributed to increasing the daily number of CVD admissions by $4.9 \%$ and $4.7 \%$, respectively.

The obtained results suggest that $\mathrm{NO}_{2}$ plays a dominant role in the higher risk of hospitalization due to cardiovascular diseases in the days when there are low concentrations of $\mathrm{NO}_{2}$, in the case of our study - average of $19.93 \mu \mathrm{g} / \mathrm{m}^{3}$, compared to the days when the concentrations of $\mathrm{NO}_{2}$ were almost minimal $\left(<4 \mu \mathrm{g} / \mathrm{m}^{3}\right)$. The fact that negative health effects of air pollutants can be observed even if the air pollutants concentrations are below the values prescribed by the WHO $[48,49,50]$ was confirmed by some authors [51].

Direct comparison of these results with the results of other studies is very complicated, on the one hand, due to the use of different health outcomes and, on the other hand, due to different methodological approach.

Association between air pollution and hospital admissions was analyzed using linear regression models, logistic regression model or variations to the Poisson model [12,52,53]. Pablo et al. [44] pointed that the results generated by the models differ and there is no sound justification for the use of one model over another. Despite the widely differing methodology approach, similar results to ours are shown in other studies [54,55]. In one study in Poland [56], authors got the results similar to ours and 
they suggested that it was rather the effect of $\mathrm{PM}_{2.5}$ which was strongly correlated with $\mathrm{NO}_{2}$. Using data on hospital admissions due to cardiovascular diseases in London and ambient $\mathrm{NO}_{2}$ levels, Poloniecki et al. [13] estimate that daily average $\mathrm{NO}_{2}$ levels, ranging from $7.8 \mathrm{ppb}$ $\left(14.66 \mu \mathrm{g} / \mathrm{m}^{3}\right)$ to $196 \mathrm{ppb}\left(368.48 \mu \mathrm{g} / \mathrm{m}^{3}\right)$, with a median of $34.3 \mathrm{ppb}\left(64.48 \mu \mathrm{g} / \mathrm{m}^{3}\right)$, are associated with hospital admissions due to acute myocardial infarction (winter only), arrhythmia and combined circulatory disease with a $2.7 \%, 2.7 \%$ and $2.4 \%$ increase per $29 \mathrm{ppb}\left(54.52 \mu \mathrm{g} / \mathrm{m}^{3}\right)$ increment in 24-hour $\mathrm{NO}_{2}$ respectively. A case crossover study in Taipei, Taiwan, has also investigated the association between $\mathrm{NO}_{2}$ level and hospital admissions due to cardiovascular diseases for the period 1997-2001. A statistically significant association was found in the case of warm and cold days. Associations were also observed for particles $\left(\mathrm{PM}_{10}\right)$, ozone $\left(\mathrm{O}_{3}\right)$, sulfur dioxide $\left(\mathrm{SO}_{2}\right)$ and carbon monoxide (CO) [57]. Similarly to our research, in most of the studies there where increases in daily $\mathrm{NO}_{2}$ concentrations that have been associated with increased admissions due to specific cardiac conditions [24,58,59] and the concentrations had the strongest association with admissions on the same day. Wong et al found a significant increase $(1.3 \%)$ in hospital admissions due to all CVD in Hong Kong, China in relation to the increase in the $\mathrm{NO}_{2}$ level by $10 \mu \mathrm{g} / \mathrm{m}^{3}$ [12]. As we have already mentioned, a direct comparison of our results with the previously stated ones is somewhat limited because of the applied categorization of the investigated pollutants. Namely, the obtained percentage of the increase in RR on average (4.9\% and $4.7 \%$ ) and the increase in $\mathrm{NO}_{2}$ concentration by $1 \mathrm{~g} / \mathrm{m}^{3}$ which seems to be fairly comparable to other studies, refer exclusively to the days when the $\mathrm{NO}_{2}$ concentration was less than $2 \mu \mathrm{g} / \mathrm{m}^{3}$, and not to the entire tested period as it was done in other studies. However, some of the authors reported no significant associations between $\mathrm{NO}_{2}$ levels and CVD admissions in all age groups [15] or ages between 5 and 64 years [12].
Some studies have shown associations between $\mathrm{SO}_{2}$ exposure and all CVD admissions [60,61], however our study did not confirm these results in the adjusted model. Few studies using data on CVD admissions in total population and the daily level of $\mathrm{SO}_{2}$ published results of epidemiological investigations similar to ours [57,62]. On the other hand, Biggeri et al. [63] in their investigation trough the 6 Italian cities (Turin, Milano, Bologna, Firenze, Rome, and Palermo), in the 1995-1999 period, show association between $\mathrm{SO}_{2}$ level and hospital admission due to CVD in total population. Hospital admissions increase by $2.8 \%$ in response to the increase in the concentration of pollution by $10 \mu \mathrm{g} / \mathrm{m}^{3}$. Sunyer et al. [14] also confirm the increase of hospital admissions due to all CVD in total population in Birmingham, London, Milan, Netherlands, Paris, Rome, and Stockholm. According to our results indicating a highly significant negative correlation between $\mathrm{SO}_{2}$ and humidity, one of the variables that can help to explain the non-significant association between $\mathrm{SO}_{2}$ and CVD admissions could be the level of air humidity. Similarly, as reported in APHEA - II study, the association of $\mathrm{SO}_{2}$ with cardiovascular admissions (both at all ages and over 65 years) was stronger in the case of lower levels of humidity (the percentage increase in all cardiovascular admissions at all ages was 1.67, 95\% CI: 0.65-2.71, per $10 \mu \mathrm{g} / \mathrm{m}^{3}$ of $\mathrm{SO}_{2}$ in the case of the lowest levels of humidity and $0.81,95 \% \mathrm{CI}: 0.43-1.19$ in the case of the highest ones) [14]. Also, our results suggest that association with CVD admissions became non-significant after adjusting for $\mathrm{NO}_{2}$, temperature and other confounding variables. Similarly, in the European APHEA II project [14] it was found that association with all cardiovascular admissions (both at all ages and above 65 years) got weaker and became non-significant after adjusting for $\mathrm{CO}, \mathrm{NO}_{2}$, black smoke, and $\mathrm{PM}_{10}$ concentration.

Responsibility of the gaseous air pollution for cardiovascular diseases has been observed in experimental [64] and epidemiological studies $[65,66]$. Although we did not 
examine potential effects of gaseous air pollution on circulatory system, the strength of our study is of significant public health interest to a large number of people exposed to air pollution in the area of Novi Sad. However, more investigations with the detailed data on the characteristics of factors such as sex, smoking habits, comorbid conditions or personal exposure to air pollutants, which were not taken into consideration because of the incomplete database, are needed to confirm or refute these findings. Still, some studies have concluded that hospital databases provide more reliable information on adverse effects of air pollution when broad diagnostic classes are used such as health indicators of the air quality [67]. It should be noted that, we used data on outdoor air pollution concentrations of $\mathrm{SO}_{2}$ and $\mathrm{NO}_{2}$ measured at fixed-point monitors, which did not represent precise exposure estimates. Some of the earlier studies $[68,69]$ indicate that such ambient concentrations may be poor surrogates for actual exposure to air pollution. Another limitation of this study could be the quality of using routinely collected health data in relation to exposure-outcome, without the possibility to separate urgent admissions due to CVD from the total number of CVD admissions. Delfino [67] has also pointed that the use of administrative data has several limitations (use of non-urgent admissions or delays in hospital admission from emergency rooms). Still, the results obtained in this study could constitute the baseline for further analytic epidemiological - environmental research.

Apart from the above limitation of the study, we can conclude that the levels of gaseous pollution throughout the period 2007-2009 in the area of Novi Sad were moderate, with a noticeable winter peak. Daily hospital admissions due to all cardiovascular diseases in population aged above 18 , without seasonal change, were significantly positively associated with the measured gaseous air pollutants in Serbia. Apart from air pollutants, daily temperature and other contributing factors like long term fluctuations or day of the week, play a significant role in its association.

\section{REFERENCE}

1. Ponce de Leon A, Anderson HR, Bland JM, Strachan DP, Bower J. Effects of air pollution on daily hospital admissions for respiratory disease in London between 1987-88 and 1991-92. J Epidemiol Comm Health. 1996;50(Suppl 1): S63-70, http://dx.doi.org/10.1136/jech.50.Suppl_1.s63.

2. Chauhan A, Johnston S. Air pollution and infection in respiratory illness. Br Med Bull. 2003;68(1):95-112, http://dx.doi. org $/ 10.1093 / \mathrm{bmb} / \mathrm{ldg} 022$.

3. Wong TW, Tam WS, Yu TS, Wun YT, Wong AHS, Wong CM. Association between air pollution and general practitioner visits for respiratory diseases in Hong Kong. Thorax. 2006;61(7):585-91, http://dx.doi.org/10.1136/ thx.2005. 051730.

4. Jevtić M, Dragić N, Bijelović S, Popović M. Air pollution and hospital admissions for chronic obstructive pulmonary disease in Novi Sad. Health Med. 2012;6(4):1207-15.

5. Anderson HR, Atkinson RW, Bremner SA, Marston L. Particulate air pollution and hospital admissions for cardiorespiratory diseases: Are the elderly at greater risk? Eur Respir J. 2003;21(Suppl 40):39S-46S, http://dx.doi.org/10.1183/ 09031936.03.00402203.

6. Dockery DW. Epidemiologic evidence of cardiovascular effects of particulate air pollution. Environ Health Perspect. 2001;109(Suppl 4):483-6, http://dx.doi.org/10.2307/3454657.

7. Brook ED, Franklin B, Cascio W, Hong Y, Howard G, Lipsett $\mathrm{M}$, et al. Air pollution and cardiovascular disease a statement for healthcare professionals from the expert panel on Population and Prevention Science of the American Heart Association. Circulation. 2004;109:2655-71, http://dx.doi. org/10.1161/01.CIR.0000128587.30041.C8.

8. Martins LC, Pereira LA, Lin CA, Santos UP, Prioli G, Luiz Odo $\mathrm{C}$, et al. Air pollution and cardiovascular diseases. Rev Saúde Pública. 2006;40(4):677-83, http://dx.doi.org/10.1590/ S0034-89102006000500018.

9. Schwartz J. Air pollution and hospital admissions for heart disease in eight US counties. Epidemiology. 1999;10:17-22, http://dx.doi.org/10.1097/00001648-199901000-00005. 
10. Morris R, Naumova E, Munasinghe R. Ambient air pollution and hospitalization for congestive heart failure among elderly people in seven large US Cities. Am J Public Health. 1995;85:1361-5, http://dx.doi.org/10.2105/AJPH.85.10.1361.

11. Morgan G, Corbett S, Wlodarczyk J. Air pollution and hospital admissions in Sydney, Australia, 1990 to 1994. Am J Public Health. 1998;88:1761-66, http://dx.doi.org/10.2105/AJPH. 88.12.1761.

12. Wong TW, Lau TS, Yu TS, Neller A, Wong SL, Tam W, et al. Air pollution and hospital admissions for respiratory and cardiovascular diseases in Hong Kong. Occup Environ Med. 1999;56:679-83, http://dx.doi.org/10.1136/oem.56.10.679.

13. Poloniecki JD, Atkinson RW, de Leon AP, Anderson HR. Daily time series for cardiovascular hospital admissions and previous day's air pollution in London, UK. Occup Environ Med. 1997;54:535-40, http://dx.doi.org/10.1136/ oem.54.8.535.

14. Sunyer J, Ballester F, Tertre AL, Atkinson R, Ayres JG, Forastiere $\mathrm{F}$, et al. The association of daily sulfur dioxide air pollution levels with hospital admissions for cardiovascular diseases in Europe (The Aphea-II study). Eur Heart J. 2003;24(8): 752-60, http://dx.doi.org/10.1016/S0195-668X(02)00808-4.

15. Ballester F, Tenías JM, Pérez-Hoyos S. Air pollution and emergency hospital admissions for cardiovascular diseases in Valencia, Spain. J Epidemiol Community Health. 2001;55:57-65, http://dx.doi.org/10.1136/jech.55.1.57.

16. Pantazopoulou A, Katsouyanni K, Kourea-Kremastinou J, Trichopoulos D. Short-term effects of air pollution on hospital emergency outpatient visits and admissions in the greater athens, Greece Area. Environ Res. 1995;69:31-6, http:// dx.doi.org/10.1006/enrs.1995.1022.

17. Milosević Z, Bogdanović D, Jović S, Stanković A, Milutinović S, Rancić N. [Influence of air pollution on hospital admissions for cardiovascular and respiratory diseases in Nis, Serbia]. Vojnosanit Pregl. 2010;67(6):473-9. Serbian, http://dx.doi.org/10.2298/VSP1006473M.

18. Burnett RT, Dales R, Krewski D, Vincent R, Dann T, Brook JR. Associations between ambient particulate sulfate and admissions to Ontario hospitals for cardiac and respiratory diseases. Am J Epidemiol. 1995;142:15-22.

19. Burnett RT, Dales RE, Brook JR, Raizenne ME, Krewski D. Association between ambient carbon monoxide levels and hospitalization for congestive heart failure in the elderly in 10 Canadian cities. Epidemiology. 1997;8:162-7, http:// dx.doi.org/10.1097/00001648-199703000-00007.

20. Dominici F, Peng RD, Bell ML, Pham L, McDermott A, Zeger SL, et al. Fine particulate air pollution and hospital admission for cardiovascular and respiratory diseases. JAMA. 2006;295:1127-34, http://dx.doi.org/10.1001/jama. 295.10.1127.

21. Morris RD. Airborne particulates and hospital admissions for cardiovascular disease: A quantitative review of the evidence. Environ Health Perspect. 2001;109(Suppl 4): 495-500, http://dx.doi.org/10.2307/3454659.

22. Kim SY, Peel JL, Hannigan MP, Dutton SJ, Sheppard L, Clark ML, et al. The temporal lag structure of short-term associations of fine particulate matter chemical constituents and cardiovascular and respiratory hospitalizations. Environ Health Perspect. 2012;120(8):1094-9, http://dx.doi. org/10.1289/ehp.1104721.

23. Bell ML, Peng RD, Dominici F, Samet JM. Emergency hospital admissions for cardiovascular diseases and ambient levels of carbon monoxide. Circulation. 2009;120:949-55, http://dx.doi.org/10.1161/CIRCULATIONAHA.109.851113.

24. Burnett R, Smith-Doiron M, Stieb D, Cakmak S, Brook JR. Effects of particulate and gaseous air pollution on cardiorespiratory hospitalizations. Arch Environ Health. 1999;54: 130-9, http://dx.doi.org/10.1080/00039899909602248.

25. Pönka A, Virtanen M. Low-level air pollution and hospital admissions for cardiac and cerebrovascular diseases in Helsinki. Am J Public Health. 1996;86:1273-80, http://dx.doi. org/10.2105/AJPH.86.9.1273.

26. Unger J, Savić S, Gál T. Modelling of the annual mean urban heat island pattern for planning of representative urban climate station network. Adv Meteorol. 2011;2011:9, http:// dx.doi.org/10.1155/2011/398613. 
27. International Statistical Classification of Disease and Related Health Problems, 10th Revision Version for 2007. World Health Organization; 2007 [cited 2013 Sept 6]. Available from: http://apps.who.int/classifications/apps/icd/ icd10online.

28. Accreditation Body of Serbia. [Decision on establishing the scope of accreditation]. Belgrade (Serbia). Accreditation number 01-131]. Belgrade: The Accreditation Body of Serbia; 2010. Serbian.

29. Republic Hydrometeorological Service of Serbia [cited 2013 Sept 6]. Available from: http:/www.hidmet.gov.rs/latin/servisi/index.php.

30. McClave, JT, Benson PG. Statistics for Business and Economics. 6th ed. New Jersey: Prentice-Hall, Inc; 1994.

31. McCullagh P, Nelder JA. Generalized Linear Models. 2nd ed. New York: Chapman \& Hall; 1989, http://dx.doi. org/10.1007/978-1-4899-3242-6.

32. Breslow NE, Day NE. Statistical methods in cancer research II. The design and analysis of cohort studies. Lyon: International Agency for Research on Cancer; 1982.

33. Rule Book on limit values, immission measuring methods, selection of sample spots criteria and data collecting. Off Gaz RS. 54/92, 30/99, 19/06.

34. WHO Regional Office for Europe. WHO Air quality guidelines for particulate matter, ozone, nitrogen dioxide and sulfur dioxide. Global update 2005. Summary of risk assessment. Copenhagen: WHO; 2006.

35. WHO Regional Office for Europe. Air quality guidelines. 2nd ed. Chapter 7.4. Copenhagen: WHO; 2000.

36. Zujic A, Radak B, Markovic D. The characteristics of the air pollution of a transition economy city: The example of Belgrade. J Serbian Chem Soc. 2007;72(8-9):889-99, http:// dx.doi.org/10.2298/JSC0709889Z.

37. Buljac M, Periš N, Buzuku M, Dabić P, Brinić S. Monthly and seasonal variations of NO, SO and black-smoke located, within the sport district in urban area, city of split, Croatia. Croatica Chemica Acta. 2012;85(2):139-45, http://dx.doi. org/10.5562/cca1966.
38. Kaushik CP, Ravindra K, Yadav K, Mehta S, Haritash AK. Assessment of ambient air quality in urban centres of Haryana (India) in relation to different anthropogenic activities and health risks. Environ Monitor Assess. 2006;122(1-3): 27-40, http://dx.doi.org/10.1007/s10661-005-9161-x.

39. Zhao C, Tie X, Wang G, Qin Y, Yang P. Analysis of air quality in Eastern China and its interaction with other regions of the world. J Atm Chem. 2006;55:189-204, http://dx.doi. org/10.1007/s10874-006-9022-1.

40. Ravindra K, Mor S, Ameena, Kamyotra JS, Kaushik CP. Variation in spatial pattern of criteria air pollutants before and during initial rain of monsoon. Environ Monit Assess. 2003;87:145-53, http://dx.doi.org/10.1023/A:1024650215970. 41. Ravindra K, Wauters E, Taygi SK, Mor S, Grieken RV. Assessment of air quality after the implementation of $\mathrm{CNG}$ as fuel in public transport in Delhi, India. Environ Monit Asses. 2006;115(1-3):405-17, http://dx.doi.org/10.1007/s10661-006$7051-5$.

42. Agarwal R, Jayaraman G, Anand S, Marimuthu P. Assessing respiratory morbidity through pollution status and meteorological conditions for Delhi. Environ Monit Assess. 2006;114(1-3):489-504, http://dx.doi.org/10.1007/s10661006-4935-3.

43. Kovats RS, Hajat S, Wilkinson P. Contrasting patterns of mortality and hospital admissions during hot weather and heat waves in Greater London, UK. Occup Environ Med. 2004;61:893-8, http://dx.doi.org/10.1136/oem.2003.012047.

44. De Pablo F, López A., Soriano LR, Tomás C. Relationships of daily mortality and hospital admissions to air pollution in Castilla-León, Spain. Atmósfera. 2006;19(1):23-9.

45. Schwartz J, Morris R. Air-pollution and hospital admissions for cardiovascular-disease in Detroit, Michigan. Amer J Epidemiol. 1995;142:23-35.

46. Khoder MI. Atmospheric conversion of sulfur dioxide to particulate sulfate and nitrogen dioxide to particulate nitrate and gaseous nitric acid in an urban area. Chemosphere. 2002;49:675-84, http://dx.doi.org/10.1016/S00456535(02)00391-0. 
47. Gouveia N, Fletcher T. Time series analysis of air pollution and mortality: effects by cause, age and socioeconomic status. J Epidemiol Community Health. 2000;54:750-5, http:// dx.doi.org/10.1136/jech.54.10.750.

48. WHO Air quality guidelines. Global update 2005. Report on a Working Group Meeting. October 18-20, 2005. Bonn: World Health Organization; 2005.

49. Ljikar V, Jevtic M. [Air quality and health risks in humans]. In: Popovic D, editor. [The health of people in Vojvodina]. Novi Sad: Serbian Matica; 2001. p. 75-73. Serbian.

50. Jevtić M. Air quality and acute and chronic respiratory diseases. Off J Rom Soc Physiol Sci. 2000;10(25):21-5.

51. Célia AA, Conceicao AF. Effects of air pollution on emergency admissions for chronic obstructive pulmonary diseases in Oporto, Portugal. Int J Environ Pollut. 2005;23:42-64, http://dx.doi.org/10.1504/IJEP.2005.006395.

52. Xu X, Li B, Huang H. Air pollution and unscheduled hospital outpatient and emergency room visits. Environ Health Perspect. 1995;103(3):286-9, http://dx.doi.org/10.1289/ ehp. 95103286.

53. Wellenius GA, Schwartz J, Mittleman MA. Particulate air pollution and hospital admissions for congestive heart failure in seven United States Cities. Am J Cardiol. 2006;97:404-8, http://dx.doi.org/10.1016/j.amjcard.2005.08.061.

54. Tsai SS, Goggins WB, Chiu HF, Yang CY. Evidence for an Association Between Air Pollution and Daily Stroke Admissions in Kaohsiung, Taiwan. Stroke. 2003;34:2612-6, http:// dx.doi.org/10.1161/01.STR.0000095564.33543.64.

55. Ulmeanu C, Caian M, Ion-Nedelcu N, Chiru M, Craciun MD, Purice F. Correlations between outdoor air pollution and hospital admission for asthma in children living in Bucharest municipality, 2004-2007. Maed J Clin Med. 2008;3(3):174-80.

56. Kowalska M, Zejda JE, Ośródka L, Chwirut A, Kondek P. [Daily hospital admissions due to cardio-respiratory diseases and ambient airpollution in Zabrze, in 2001-2005]. Probl Hig Epidemiol. 2008;89(1):41-6. Polish.

57. Chang CC, Tsai SS, Ho SC, Yang CY. Air pollution and hospital admissions for cardiovascular disease in Taipei, Taiwan.
Environ Res. 2005,98:114-9, http://dx.doi.org/10.1016/j.envres.2004.07.005.

58. Linn W, Szlachcic Y, Gong HJ, Kinney P, Berhane K. Air pollution and daily hospital admissions in metropolitan Los Angeles. Environ Health Perspect. 2000;108:427-34, http:// dx.doi.org/10.1289/ehp.00108427.

59. Ye F, Piver W, Ando M, Portier C. Effects of temperature and air pollutants on cardiovascular and respiratory diseases for males and females older than 65 years of age in Tokyo, July and August, 1980-1995. Environ Health Perspect. 2001;109:355-9, http://dx.doi.org/10.1289/ehp.01109355.

60. Klein M, Tolbert PE, Peel JL, Metzger KB, Flanders WD. The distributed lag between ambient air pollution and cardiorespiratory emergency department visits. Epidemiology. 2004;15(4):S61-2.

61. Ballester F, Rodríguez P, Pérez-Hoyos S, Bellido J, Arribas F, Saurina C, et al. Relationship between gaseous air pollutants and cardiovascular admissions: A study in 14 Spanish cities. Epidemiology. 2004;15(4):S25-6, http://dx.doi. org/10.1097/00001648-200407000-00052.

62. Prescott GJ, Cohen GR, Elton RA, Fowkes FGR, Agius RM. Urban air pollution and cardiopulmonary ill health: A 14.5 year time series study. Occup Environ Med. 1998;55: 697-704, http://dx.doi.org/10.1136/oem.55.10.697.

63. Biggeri A, Bellini P, Terracini B, editors. [Meta-analysis of the Italian studies on short-term effects of air pollution]. Epidemiol Prev. 2001;25(Suppl 2):1-71. Italian.

64. Jeffrey PK. Effects of cigarette smoke and air pollutants on the lower respiratory tract. In: Holgate S, Samet J, Koren H, Maynard R, editors. Air pollution and health. San Diego: Academic Press; 1999. p. 219-68, http://dx.doi.org/10.1016/ B978-012352335-8/50087-9.

65. Peters A, Doring A, Wichmann HE, Koenig W. Increased plasma viscosity during an air pollution episode: A link to mortality? Lancet. 1997;349:1582-7, http://dx.doi. org/10.1016/S0140-6736(97)01211-7.

66. Pekkanen J, Brunner EJ, Anderson HR, Tiittanen P, Atkinson RW. Daily concentrations of air pollution and plasma 
fibrinogen in London. Occup Environ Med. 2000;57:818-22, http://dx.doi.org/10.1136/oem.57.12.818.

67. Delfino RJ, Becklake MR, Hanley JA. Reliability of hospital data for population-based studies of air pollution. Arch Environ Health. 1993;48(3):140-6, http://dx.doi.org/10.1080/00 039896.1993.9940812.

68. Sarnat J, Brown K, Schwartz J, Coull B, Koutrakis P. Ambient gas concentrations and personal particulate matter exposures: implications for studying the health effects of particles. Epidemiology. 2005;16:385-95, http://dx.doi. org/10.1097/01.ede.0000155505.04775.33.

69. Sarnat J, Schwartz J, Catalano P, Suh H. The role of gaseous pollutants in particulate matter epidemiology: confounder or surrogate? Environ Health Perspect. 2001;109:1053-62, http://dx.doi.org/10.1289/ehp.011091053.

This work is available in Open Access model and licensed under a Creative Commons Attribution-NonCommercial 3.0 Poland License - http://creativecommons.org/ licenses/by-nc/3.0/pl/deed.en. 